\title{
Ocean temperature oscillations enable reappearance of blue mussels Mytilus edulis in Svalbard after a 1000 year absence
}

\author{
Jørgen Berge ${ }^{1, *}$, Geir Johnsen ${ }^{1,2}$, Frank Nilsen ${ }^{1}$, Bjørn Gulliksen $^{1,3}$, Dag Slagstad $^{4}$ \\ ${ }^{1}$ University Centre in Svalbard, 9171 Longyearbyen, Norway \\ ${ }^{2}$ Norwegian University of Technology and Science, 7469 Trondheim, Norway \\ ${ }^{3}$ Norwegian Fishery College, University of Tromsø, 9027 Tromsø, Norway \\ ${ }^{4}$ SINTEF Fisheries and Aquaculture, 7465 Trondheim, Norway
}

\begin{abstract}
We report the first observations of settled blue mussels Mytilus edulis L. in the high Arctic Archipelago of Svalbard for the first time since the Viking Age. A scattered population was discovered at a single site at the mouth of Isfjorden in August 2004. Our data indicate that most mussels settled there as spat in 2002, and that larvae were transported by the West Spitsbergen Current northwards from the Norwegian coast to Svalbard the same year. This extension of the blue mussels' distribution range was made possible by the unusually high northward mass transport of warm Atlantic water resulting in elevated sea-surface temperatures in the North Atlantic and along the west coast of Svalbard.
\end{abstract}

KEY WORDS: Mytilus edulis · Arctic Atlantic Water transport $\cdot$ Remote sensing $\cdot$ Simulated transport time $\cdot$ Sea-surface temperature $\cdot$ Temperature oscillations $\cdot$ Holocene

\section{INTRODUCTION}

During the last 120000 yr world ocean temperatures have varied significantly (Rahmstorf 2002). Since the last ice age a maximum in sea-surface temperatures (SST) peaking at around $9000 \mathrm{yr}$ BP also affected the Arctic through an enhanced northward heattransportation by the Gulf Stream system (Rahmstorf 2002, Sarnthein et al. 2003). Distribution patterns of blue mussels Mytilus edulis L. in the high Arctic indicate that this thermophilous mollusc was abundant along the west coast of Svalbard during warm intervals (Salvigsen et al. 1992, Salvigsen 2002, Lønne \& Nemec 2004) in the Holocene (see Fig. 1a). Fossil records for the last ice age showed no occurrence of the blue mussels in Nordic seas, and it probably survived only south of the British Isles before spreading northwards and re-immigrating into Svalbard waters approximately 11500 yr BP (Mangerud 1977, Mangerud \& Svendsen 1992, Salvigsen et al. 1992, Salvigsen 2002). Herein we demonstrate the linkage between the reappearance of live blue mussels in Svalbard after 1000 yr absence and oscillations in ocean climate.

Blue mussels have not been present at Svalbard for the last 1000 yr (Salvigsen 2002, Lønne \& Nemec 2004), and not in great abundances for the last $7000 \mathrm{yr}$ (Fig. 1a). The period between 10700 and 7700 yr BP has been identified as a Holocene thermal optimum (Duplessy et al. 2001, Rahmstorf 2002, Andreev et al. 2004) with summer SST reaching $8^{\circ} \mathrm{C}$ and a concomitant enhancement in the West Spitsbergen Current (Sarnthein et al. 2003) (Fig. 1b). With regards to the well-documented distribution pattern of blue mussels during the Holocene, the discovery of a viable population in Svalbard raises important questions regarding the effects of short-term ocean climate oscillations in the high Arctic. Bearing in mind the blue mussels' sensitivity to short-term marine temperature fluctuations (Peacock 1989, Honkoop \& van der Meer 1998), this re-appearance suggests that recent water temperatures approach those of the mediaeval warm period when Viking settlements were founded in Iceland, 

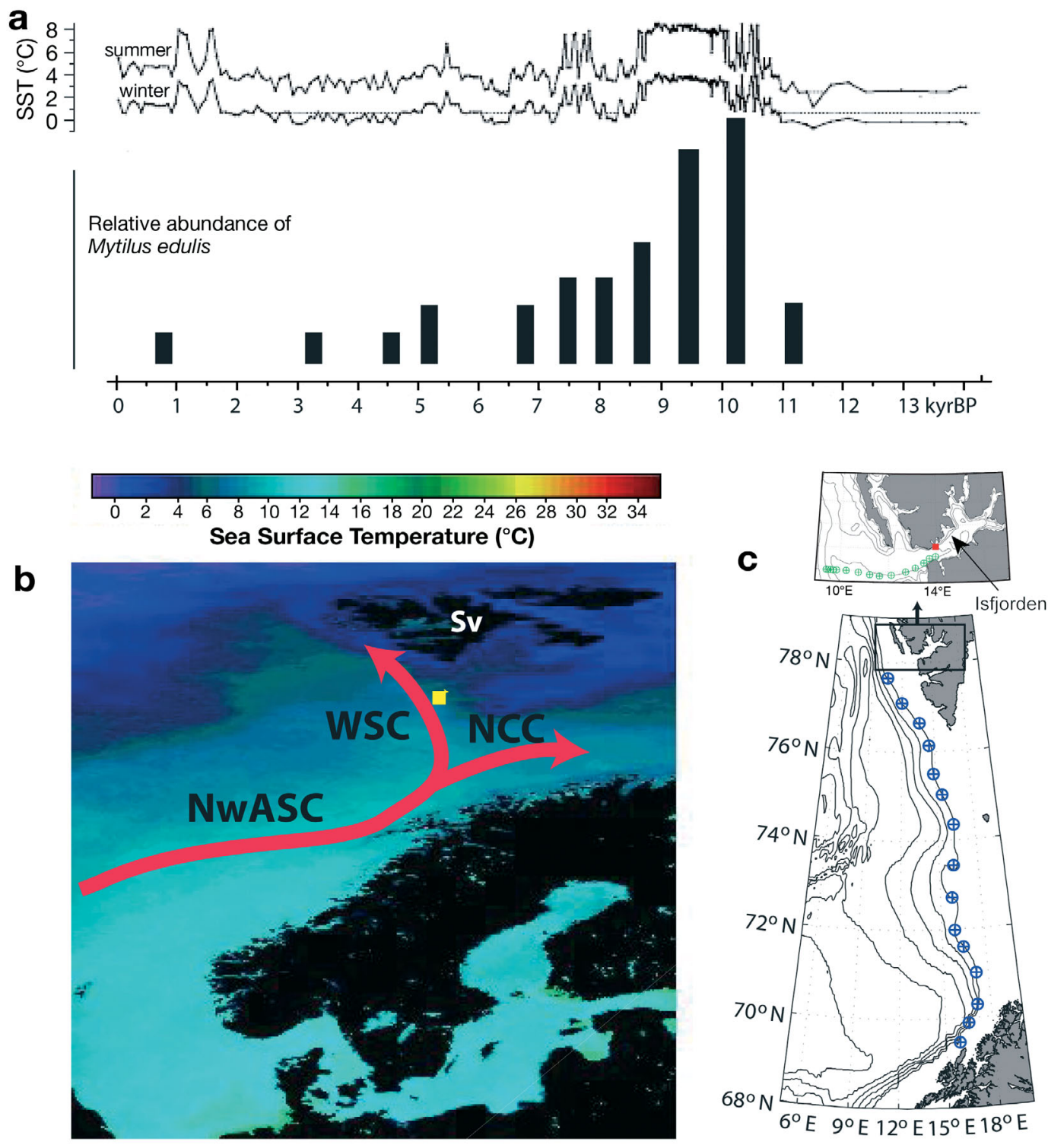

Fig. 1. (a) Estimated sea-surface temperatures (SST) for western Barents shelf (yellow square in b) from 13000 yr BP to present (from Sarnthein et al. 2003), and relative abundance of radiocarbon-dated blue mussels in Svalbard archipelago (data redrawn and rescaled from Salvigsen [2002] into calendar years using CALIB 5.0.1); kyr: 1000 yr. (b) Aqua Satellite (MODIS instrument) image of cumulative SST from 1 July 2002 to 31 August 2004 showing warm and saline Norwegian Atlantic Slope Current (NwASC) flowing along shelf break of Norwegian coast, and separating into North Cape Current (NCC) and West Spitsbergen Current (WSC). Svalbard (Sv); yellow square: sampling site of core used to estimate Holocene climate condition (Sarnthein et al. 2003). (c) Blue circles: modelled transport route of NwASC-WSC water from Lofoten/Vesterålen area $\left(69^{\circ} \mathrm{N}\right)$ to Isfjorden $\left(78^{\circ} \mathrm{N}\right)$; green circles: transect for hydrographical measurements from 1999 to present (see Fig. 4d-i)

Greenland and Newfoundland. However, although temperatures in the world oceans has increased during the last $50 \mathrm{yr}$ (Levitus et al. 2000, Fukasawa et al. 2004), interannual fluctuations have been pronounced (Levitus et al. 2000, Johannessen et al. 2004). The present study examines interannual variations in ocean temperatures and northward transport of Atlantic water have caused a northward extension of the distribution range of blue mussels.

\section{MATERIALS AND METHODS}

Currents. Transport effects in the eastern branch of the Norwegian Atlantic Current (NwAC), the Norwegian Atlantic Slope Current (NwASC) (Orvik \& Niiler 2002, Orvik \& Skagseth 2003), and further north in the West Spitsbergen Current (WSC) were studied (Fig. 1b,c). These current systems transport Atlantic Water (AW) as an extension of the Gulf Stream system. 
AW has a salinity of $>34.90$ and a temperature of $>3^{\circ} \mathrm{C}$ when it enters the Arctic Ocean (Swift \& Aagaard 1981). Here it meets fresher and colder Arctic Water (ArW) with a salinity of 34.3 to 34.8 and temperatures below $0^{\circ} \mathrm{C}$. The minimum transport time of water masses in relatively deep layers (100 to $200 \mathrm{~m}$ ) from northern Norway (Andøya in the Lofoten and the Vesterålen area at $\sim 69^{\circ} \mathrm{N}$, see Fig. 1) to the shelf areas outside Isfjorden in Svalbard (a distance of approx. $1000 \mathrm{~km}$, see transect in Fig. 1c) is estimated to be between 32 and $38 \mathrm{~d}$ at a maximum average current speed of 0.30 to $0.35 \mathrm{~m} \mathrm{~s}^{-1}$. These estimates are based on water-current time series and Lagrangian drifter observations of the NwASC (Orvik \& Niiler 2002, Orvik \& Skagseth 2003, Schauer et al. 2004, Ø. Skagseth pers. comm.). In terms of interannual variability, the annual mean mass transport of AW in the Svinøy section (ranging from approximately $62^{\circ} \mathrm{N}, 5^{\circ} \mathrm{E}$ to $68^{\circ} \mathrm{N}, 12^{\circ} \mathrm{W}$, and used for estimation of mass transport by the NwAC) was at an absolute minimum in 2001 and increased to an absolute maximum in 2002 (Orvik \& Skagseth 2003). The estimated minimum transport time is based on current sections south and north of the presumed transport pathway of Mytilus edulis larvae, and a linear variation between a relatively strong current in the Svinøy section to a weaker current along West Spitsbergen is assumed. Also, the maximum current speeds used in our estimates are representative for winter, the current speed during summer being generally lower. Hence, a numerical model is necessary to calculate transport time in the spring and summer months.

Estimations of transport time for particles in surface layers over the same distance (approximately $1000 \mathrm{~km}$ ) were simulated using a hydrodynamic model based on the basic Navier-Stokes equations and solved by a finite difference scheme. The model used vertical $z$ coordinates (i.e. each model level had a fixed thickness except for the surface level and that next to the bottom); for a detailed model description, see StøleHansen \& Slagstad (1991), Slagstad \& McClimans (in press). The large-scale North Atlantic circulation pattern interacts with local physical forcing (wind, water density and local topography) to produce the hydrodynamics in this region. A high-resolution model is necessary to resolve important features such as eddies or the meandering Polar Front, and thus a nested model was applied. A large-scale model encompassing the Nordic Seas was established with a horizontal gridpoint distance of $50 \mathrm{~km}$. This model produced the boundary conditions for a regional model with a grid resolution of $20 \mathrm{~km}$ which, in turn, produced boundary conditions for a model domain covering the Barents Sea and NE Norwegian Sea; this model had a horizontal resolution of $4 \mathrm{~km}$. Coupling of models was achieved by a flow-relaxation scheme (Martinsen \& Engedahl 1987).

The advection scheme used for particles followed the 4th-order Runge-Kutta method with a time step of 6 min, whereby particles started their drift from release sites on the shelf outside Andøya.

Temperature data and biological samples. Seawater temperature and salinity along West Spitsbergen were measured with a SeaBird Electronics SBE911 CTD profiler onboard RV 'Håkon Mosby' (University of Bergen) in 2002 and 2004 and RV 'Sarsen' (Institute of Marine Research, Bergen) in 2003. The CTD instruments were calibrated with bottle samples (uncertainty of salinity after calibration ca. 0.001). Remotely sensed SST images were made by the moderate resolution imaging spectroradiometer (MODIS) deployed on the 'Aqua' satellite (EOS PM, MODIS Land Rapid Response Team, NASA/GSFC) with a resolution of $4 \mathrm{~km} \mathrm{pixel}^{-1}$. The revisit time of MODIS is 1 to $2 \mathrm{~d}$. All biological samples were collected by SCUBA divers in August and September 2004. Tidal amplitude in Isfjorden is $\sim 1.3 \mathrm{~m}$.

\section{RESULTS AND DISCUSSION}

\section{Mytilus edulis population}

The population of blue mussels was discovered in August 2004 SE of the rocky islet Sagaskjæret, Isfjorden (Fig. 1c) at 4 to $7 \mathrm{~m}$ depth. The site was close to an area containing abundant remains of Holocene blue mussels, some of which were radiocarbon-dated to $\sim 7200$ yr BP (Fig. 2), and it was characterised by an uneven distribution of mussels ( 0.5 individuals $\left.\mathrm{m}^{-2}\right)$. Of these, 11 specimens were haphazardly collected, ranging from 2.7 to $5.5 \mathrm{~cm}$ in length, most specimens being 2.7 to $3.4 \mathrm{~cm}$. Our data indicate that a seeding stock of blue mussel larvae, originating from the Norwegian coast, was transported by the WSC, settled at the mouth of Isfjorden, and eventually established a viable population (see next subsection and Fig. 1b,c).

\section{Origin of blue mussel population}

The western coast of Spitsbergen has been relatively intensively sampled during the last 30 yr (e.g. Rozycki 1987, Palerud et al. 2004). Sagaskjæret in particular has been used as a regular sampling locality by scientific divers from UNIS over the last decade. Thus, based on the long record of no observations of blue mussels at Svalbard, it is reasonable to assume that the species has recently extended its distribution range northwards. There are 3 means of transportation that 


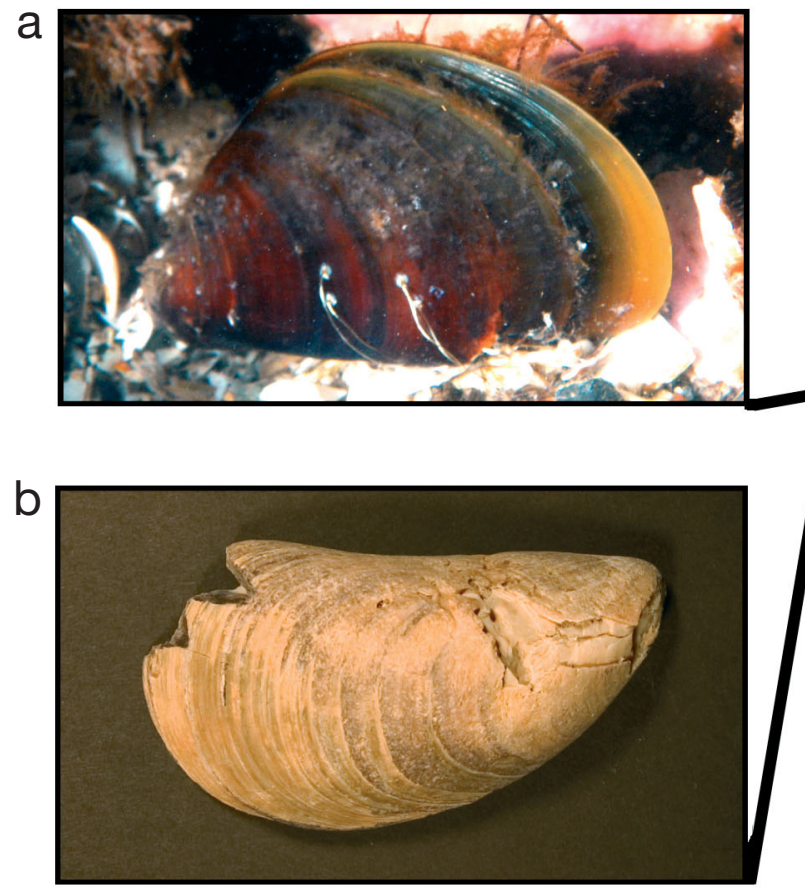

could have brought blue mussels to Svalbard: flotsam (adult specimens attached to a floating substrate), ballast water, or ocean currents. The first of these is unlikely, as the new population was relatively large, homogeneous and widespread around Sagaskjæret. If drifting had been the means of transport, this would probably have resulted in a very small and heterogeneous group of specimens in one small defined area. The ballast water released at the 2 ports in Isfjorden (Barentsburg and Longyearbyen) consists strictly of offshore surface water from approx. $70^{\circ} \mathrm{N}$ latitude, and as the density of blue mussel larvae in offshore waters must necessarily be very low, it is unlikely to have enabled the establishment of such a numerous and homogenous population as that at Sagaskjæret. In addition, ballast water is released in the ports (local environmental guidelines and local governmental authorities, pers comm.), which are far distant from Sagaskjæret. Thus, northward transportation of blue mussel larvae by the NwAC is the most logical dispersal route.

Based on both their size and the absence of spat and fully developed specimens in exposed areas of Sagaskjæret, all observed mussels must be older than $1 \mathrm{yr}$ and thus also have survived at least 1 winter. The absence of spat from August to September 2004, during 2 site examinations by SCUBA diving, indicates a lack of both local reproduction and transport of larvae in 2004. Furthermore, all mussels found were partly covered with coarse sediments, well-protected from ice-scouring in leads or cracks in the bedrock. The lack of blue mussel spat and fully developed specimens in exposed areas or in the intertidal zone, is primarily related to ice-scouring at 0 to $4 \mathrm{~m}$ depth (no perennial kelp forest at $<4 \mathrm{~m}$ depth). The largest mussel $(5.5 \mathrm{~cm}$ ) had well-developed gonads, and both valves were overgrown with bryozoans and cirripedes, indicating that it was at least 1 yr older than the other specimens, which bore very little epifauna. Gonad development in this species has been shown to be either delayed or to cease completely in water temperatures below $7^{\circ} \mathrm{C}$ (Honkoop \& van der Meer 1998). A recent study in Iceland (Thorarinsdóttir \& Gunnarson 2003), however, reported continuous although strongly delayed gonad development in Mytilus edulis at temperatures approaching $0^{\circ} \mathrm{C}$. The developed gonads and epifauna on the largest (oldest) specimen in the present study suggest that settlement of mussels at Sagaskjæret occurred on at least 2 different occasions.

\section{Transportation of larvae}

\section{Mass transport of Atlantic Water}

The NwASC is at its shortest distance (Orvik \& Niiler 2002, Orvik \& Skagseth 2003) from the Norwegian coastline around Andøya at $69^{\circ} \mathrm{N}$. North of this site the NwASC divides (Fig. 1b) into the North Cape Current (NCC) and the WSC, leading into the Barents Sea and 
to West Spitsbergen, respectively. The shortest and hence the most logical transport route for blue mussel larvae to Svalbard would entail a seeding-stock area of larvae in coastal waters of the Norwegian coast at $69^{\circ} \mathrm{N}$. Based on a maximum average current speed of 0.30 to $0.35 \mathrm{~m} \mathrm{~s}^{-1}$ (Orvik \& Niiler 2002), larvae would have an estimated transport time of 32 to $38 \mathrm{~d}$ in the core layers of the WSC between Andøya and Svalbard (Fig. 1c). Larvae originating further north would be transported into the Barents Sea and not northwards to Svalbard (Fig. 1c). Further south, the transport time would gradually increase. The total duration of the pelagic larval stages (trochophore, veliger and pediveliger larvae) is usually around 30 to $35 \mathrm{~d}$, but may be extended in suboptimal (e.g. low temperature) conditions (Bayne 1965, 1976). Thus, our estimated minimum transport time of 32 to $38 \mathrm{~d}$ corresponds to the lifespan of blue mussel larvae. These estimations, however, only take into account transport in deeper layers (typically 100 to $200 \mathrm{~m}$ ), and are thus not directly relevant for the potential transport of blue mussel larvae between the Norwegian mainland and Svalbard. Although there are few data on the transport depths of Mytilus larvae (but see e.g. Bayne 1964), it is reasonable to assume that such transport is largely confined to surface layers. Surface-layer transport is, however, typically slow and could require up to 3 to 4 mo for the same distance (next section).

\section{Transport in surface layers}

To evaluate the possibility of surface-layer transport, we simulated the transport of larvae between Andøya and Svalbard using a previously developed model (Fig. 3) for the area in question (Støle-Hansen \& Slagstad 1991, Slagstad \& McClimans in press). In general, current speeds in surface layers are faster from April to June than in July and August. In our model, larvae released late in June 2002 and 2003 generally failed to reach Svalbard until late September, a period significantly exceeding the longevity of blue mussel larvae. Earlier in the year, however, transport times were much shorter (Fig. 3b,c), with a minimum of $47 \mathrm{~d}$ for larvae released at the end of May 2002. Corresponding simulations for 2001 and 2003 produced significantly longer transport times.

Spawning of blue mussels is highly temperaturedependent and occurs typically at temperatures around 8 to $10^{\circ} \mathrm{C}$ (Bayne 1965, 1976, Hovgaard et al. 2001, Thorarinsdóttir \& Gunnarson 2003). Based on remotely sensed monthly average SST data (MODISAqua), the western and northern coastline of Norway typically has an SST of 8 to $10^{\circ} \mathrm{C}$ in June. Also, SST data (Fig. 4a,c) for 2002 to 2004 clearly demonstrate that SST was significantly higher in the North Atlantic in 2002 than in the other years. Hence, it is reasonable to assume that in 2002 spawning of blue mussels may have occurred as early as late May or early June. In addition, blue mussel larvae tend to sink as a response to lower temperatures $\left(5^{\circ} \mathrm{C}\right.$ : Bayne 1964). As larvae are transported northwards towards Svalbard, temperatures would gradually sink to this level and, as a result, larvae would possibly come into contact with the faster sub-surface currents.

Although our simulations clearly demonstrate that the transport time of particles in the surface layers between Andøya and Svalbard are usually significantly longer than the lifespan of blue mussel larvae, they also indicated that such transport may be a realistic, although extremely rare, scenario. Conditions in 2002 seem to have been most favourable in this respect.

\section{Oceanographic conditions along the west coast of Svalbard}

Isfjorden is a broad fjord with no distinct sill at its mouth, and is therefore directly linked to the shelf and slope area along West Spitsbergen where AW is guided from the WSC towards the mouth of the fjord. The WSC is considered the major pathway both for heat and water-volume export to the Arctic Ocean (Aagaard \& Greisman 1975), and the portion of the WSC flowing over the upper part of the continental slope of Spitsbergen (i.e. the warm core of the WSC) comprises the main conductor of heat into the Arctic Ocean (Gammelsrød \& Rudels 1983, Aagaard et al. 1987, Schauer et al. 2004, Fig. 1b). Hydrographic measurements have been conducted every autumn along West Spitsbergen and in Isfjorden since 1999 (F. Nilsen unpubl., Fig. 1b), and these show that 2002 was a special year during which AW managed to enter Isfjorden in the autumn (Fig. $4 \mathrm{~d}-\mathrm{g}$ ). The same abnormal situation in 2002 was also reported from Storfjorden (SE of Isfjorden), with AW being the dominant water mass (Skogseth et al. 2005). The shelf areas outside Isfjorden were also flushed with AW in 2003 (Fig. 4e-h), but these water masses did not penetrate deeply into Isfjorden. The along-shore wind component was an important factor controlling this interannual variability. During summer and early autumn, when the fjords and shelf waters have a 2-layered stratification (Fig. 4g-i), the normal wind direction is from S-SE. This is not a favourable direction for transporting AW onto the shelf areas, as demonstrated by a 2-layered costal upwelling model (Cushman-Roisin et al. 1994) (Fig. 5a). However, a northerly wind along the West Spitsbergen coast (Fig. 5b) will produce an offshore 
a

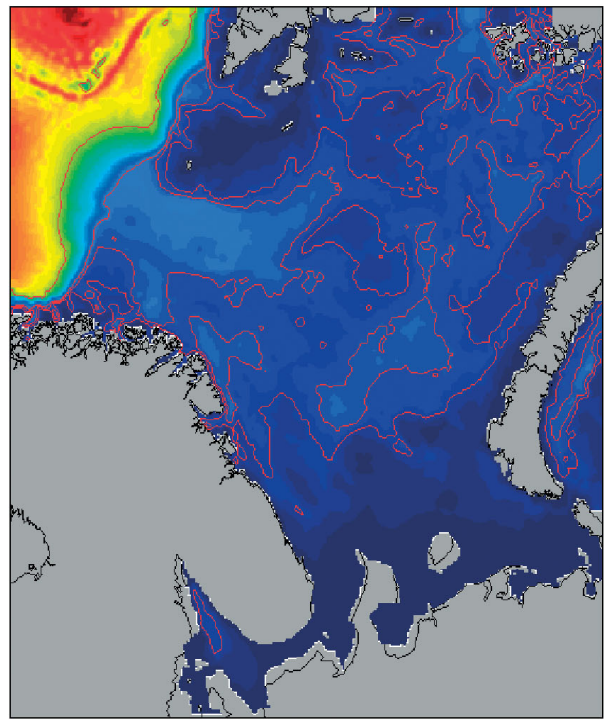

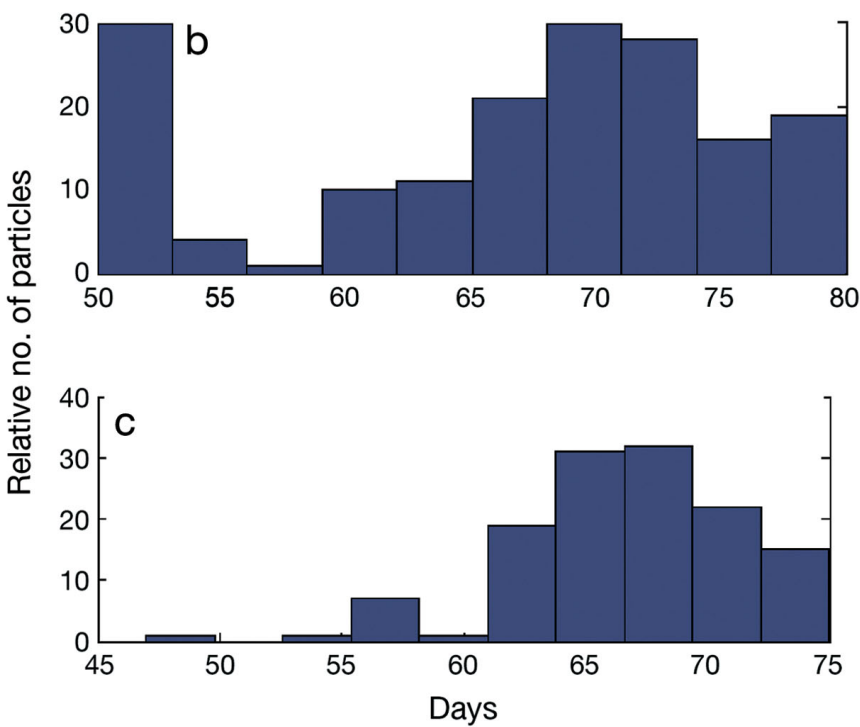

Fig. 3. (a) Model domain, nested model. (b,c) Simulated drift-time for particles (considered equivalent to blue mussel larvae) arriving at west coast of Svalbard on (b) 15 July 2002 and (c) 10 July 2002; particles were released at Andøya at end of May

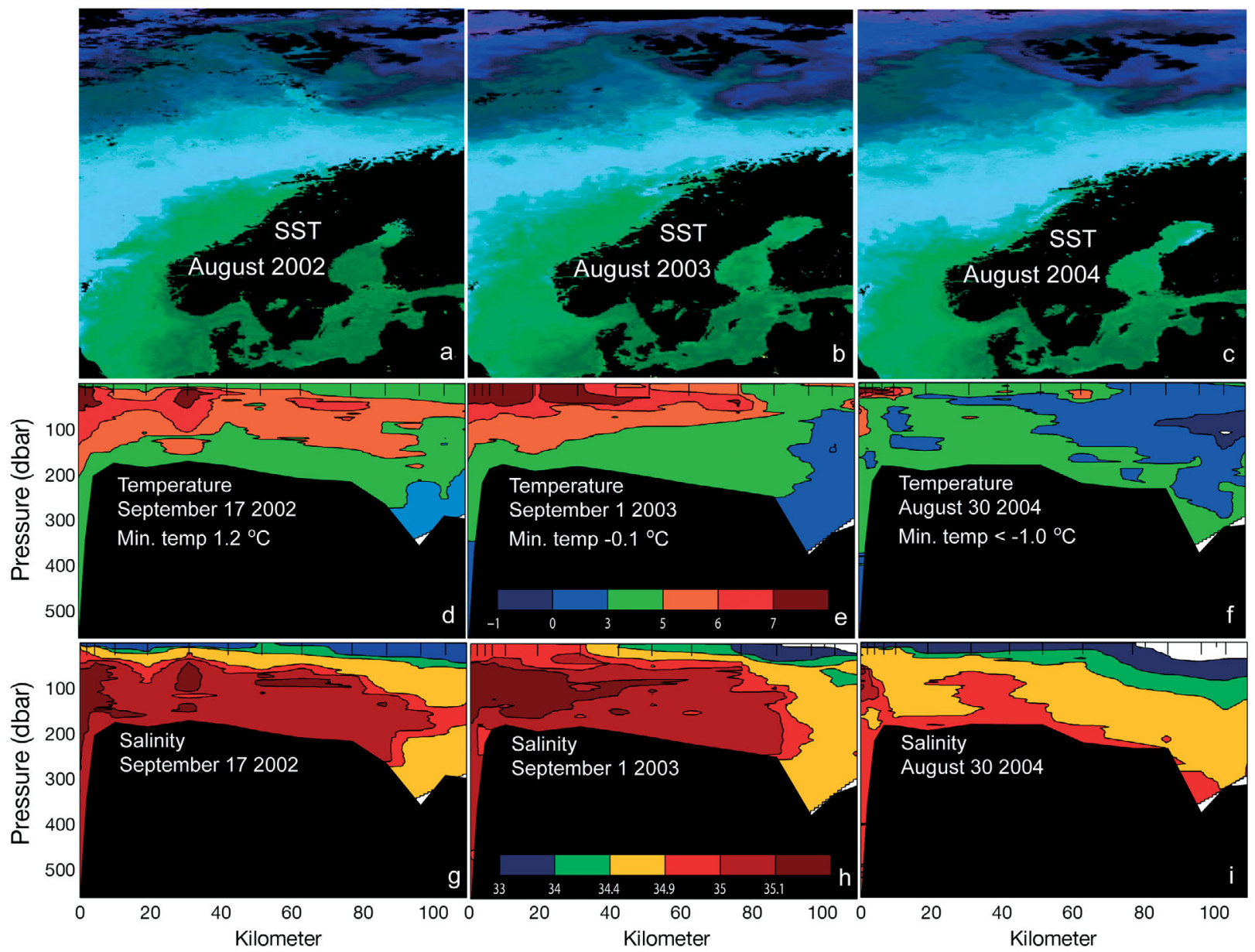

Fig. 4. (a-c) MODIS (moderate resolution imaging spectroradiometer) images of cumulative SST for August 2002,2003 and 2004 (colour scale as in Fig. 1). (d-i) CTD measurements on shelf and slope areas outside Isfjorden in positions indicated by green circles in Fig. 1c (black whiskers on top of each image correspond to the green circles). Temperature $(d-f)$ and salinity $(g-i)$ measured in $(\mathrm{d}, \mathrm{g})$ autumn 2002, $(\mathrm{e}, \mathrm{h}) 2003$ and $(\mathrm{f}, \mathrm{i})$ 2004. Sections begin at warm core of WSC confined to steep slope on the left-hand side, and end at mouth of Isfjorden on right-hand side of images 
Ekman drift of cold and fresh water with a compensating onshore transport of warm and saline water (AW) in the lower layer, thereby increasing the topographically steered flow of AW towards Isfjorden (confirmed by numerical model simulations using the Bergen Ocean Model, F. Nilsen unpubl.). Using hindcast wind stress data (Reistad \& Iden 1998) from the shelf area, the wind direction was calculated during June and
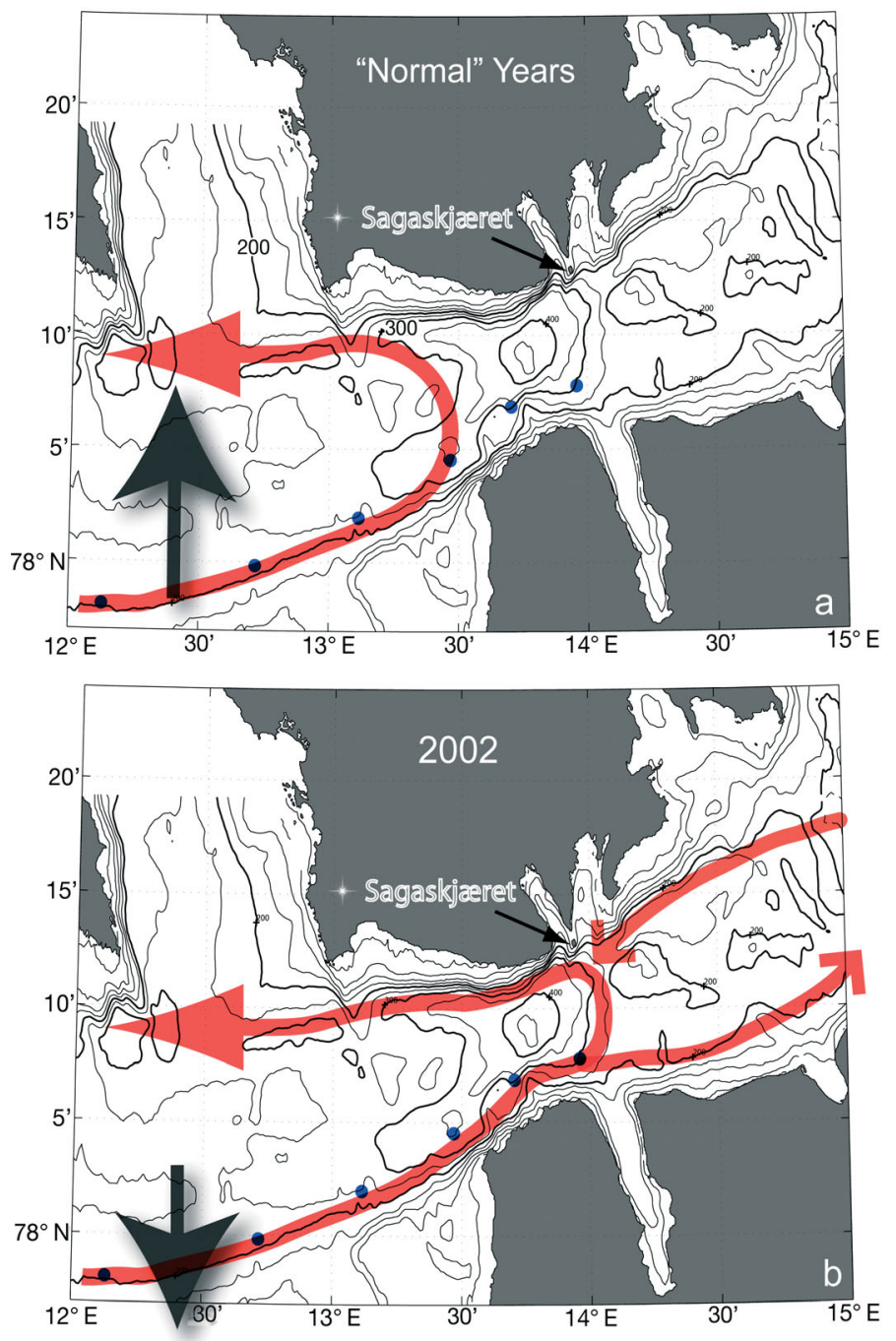

Fig. 5. Autumn current system in (a) 'normal' years and (b) unusual 2002 situation in Isfjorden and the adjacent shelf areas. Red arrows show topographically diverted AW (Atlantic Water) branch emanating from WSC and flowing in layers below surface layer towards mouth of Isfjorden. Isobaths contoured from data of Norwegian Hydrographic Service; blue circles: positions of easternmost stations in CTD sections in Fig. 4(d-i). (a) In 'normal' years with southerly wind component (black arrow), AW flowing towards Isfjorden is prevented from entering mouth of Isfjorden by front system created by inflowing AW and westwards wind-induced counterflow in sub-surface water layers (e.g. Fig. 4h); (b) in 2002, this front was absent, mainly due to a weak northerly wind (black arrow) component, and hence, AW were able to penetrate the mouth of Isfjorden and further into the fjord
July for the 6 yr from 1999 to 2004. From these data, it is evident that 2002 was characterised by a northerly wind. Thus, in addition to a generally increased northward mass transport in the North Atlantic (Orvik \& Skagseth 2003) in 2002, the northerly wind along western Spitsbergen further provided increased opportunities for AW, and hence also blue mussel larvae, to enter Isfjorden. The offshore transport in the surface layer (Fig. $4 \mathrm{~g}-\mathrm{i}$ ) also reduces the probability of blue mussel larvae being transported to Svalbard by way of ballast water and eventually reaching and settling at Sagaskjæret.

Based on these facts, on to the interannual variations in remotely-sensed SST (Fig. $4 \mathrm{a}-\mathrm{c}$ ) and in situ measurements (Fig. 4d,e) west of Spitsbergen in 2002 to 2004, and on the estimated transport times for blue mussel larvae in the WSC, we thus hypothesise that the majority of blue mussels were transported as larvae in unusually warm water by the WSC from the mainland of Norway to Spitsbergen during the summer of 2002 (Fig. 4). Settlement and growth of larvae to adult mussels at Sagaskjæret in Isfjorden was made possible by to an increased autumn SST in 2002 that also was evident in 2003 (Fig. 4a-c). The flux of AW into Isfjorden in August and September 2002 was confirmed by the anomalous appearance of the temperate planktonic diatom Skeletonema costatum and the mass occurence (B. Johnsen \& C. von Quillfeldt unpubl.) of Atlantic cod Gadus morhua and Atlantic salmon Salmo salar).

\section{Reliability of Mytilus edulis as temperature indicator}

It has recently been argued (Feder et al. 2003) that the distributional patterns of Mytilus edulis and $M$. trossulus are not reliable indicators of temperature changes, as mussels may form refugee populations in areas with highly variable salinity conditions in order to avoid predation. We argue that salinity is not a relevant factor for the distribution of blue mussels on the Norwegian coast and Svalbard, as salinity levels here are relatively higher and more constant than in arctic Alaska. Also, most of the localities around Svalbard, where ${ }^{14} \mathrm{C}$-dated blue mussels have been found, are more comparable to those at Sagaskjæret today (Fig. 2) than to the localities where relict populations are found in Arctic Alaska today. The environmental conditions at Sagaskjæret today are characterised by a strong and year-round influx of warm and saline modified AW from WSC, providing favourable conditions for the most important predators of blue mussels (Feder et al. 2003). In addition, despite intensive sampling along the western coast of Spitsbergen during the last $30 \mathrm{yr}$ 
(see subsection 'Origin of blue mussel population'), no records of settled blue mussels has been obtained. Combined, these factors reduce the probability of Isfjorden having a relict population similar to those in Arctic Alaska. Hence it is highly probable that the newly established blue mussel population is a direct response to a recent increase in SST.

\section{CONCLUSIONS}

Our analyses of the physical oceanic conditions affecting the Svalbard Archipelago and the newly discovered population of blue mussels at Sagaskjæret, Isfjorden, support the hypotheses that the population is young, predominantly established during the summer and/or autumn of 2002, and was founded by larvae transported to Spitsbergen by the WSC. The analyses further indicate that this event was made possible only through a simultaneous occurrence of a set of independent factors - increased northward mass transport of AW by the WSC, favourable wind conditions affecting the Isfjord-system and elevated SST affecting both spawning and settlement of blue mussels. Our main conclusion is, however, that increased mass transport of AW by the WSC will necessarily lead to an increased influx of temperate species to the west coast of Svalbard. Furthermore, provided that the temperature in the Arctic Ocean continues to increase, an increased number of these boreal or temperate species will also successfully establish viable populations in the high Arctic.

However, regardless of their means of transportation, SST on the west coast of Svalbard has for the last 2 to 3 yr been sufficiently high to sustain survival, growth and gonad production of blue mussels.

Acknowledgements. We thank S. Frantzen (HiF, Norway), C. von Quillfeldt (NP, Norway), A. Wolfe (UNIS), B. Jakobsen (UNIS), H. Christiansen (UNIS) and R. Langvatn (UNIS) for their help during the process of writing this manuscript. In addition, we thank Jan Mangerud and Torleiv Brattegaard and 2 other anonymous referees for their constructive input to an earlier draft.

\section{LITERATURE CITED}

Aagaard K, Greisman P (1975) Toward new mass and heat budgets for the Arctic Ocean. J Geophys Res 80:3821-3827

Aagaard K, Foldvik A, Hillman SR (1987) The West Spitbergen Current: disposition and water mass transformation. J Geophys Res 92(C4):3778-3784

Andreev A, Arasov P, Schwamborn G, Ilyshuk B and 5 others (2004) Holocene paleoenvironmental records from Nikolay Lake, Lena River Delta, Arctic Russia. Paleogeogr Paloeclimatol Paleoecol 209:197-217

Bayne BL (1964) The responses of the larvae of Mytilus edulis (L.) to light and gravity. Oikos 15:162-174
Bayne BL (1965) Growth and the delay of metamorphosis of the larvae of Mytilus edulis (L.). Ophelia 2:1-47

Bayne BL (1976) The biology of mussel larvae. In: Bayne BL (ed) Marine mussels: their ecology and physiology. Cambridge University Press, Cambridge, p 81-120

Cushman-Roisin B, Asplin L, Svendsen H (1994) Upwelling in broad fjords. Cont Shelf Res 14:1701-1721

Duplessy, JC, Ivanova E, Murdmaa I, Paterne M, Labeyrie L (2001) Holocene paleoceanography of the northern Barents Sea and variations of the northward heat transport by the Atlantic Ocean. Boreas 30:2-16

Feder HM, Norton D, Geller JB (2003) A review of apparent 20th century changes in the presence of mussels (Mytilus trossulus) and macroalgae in arctic Alaska, and of historical and paleontological evidence used to relate mollusc distributions to climate change. Arctic 56:391-404

Fukasawa M, Freeland H, Perkin R, Watanabe T, Uchida H, Nishina A (2004) Bottom water warming in the North Pacific Ocean. Nature 427:825-827

Gammelsrød T, Rudels B (1983) Hydrographic and current measurements in the Fram Strait, August 1981. Polar Res $1: 115-126$

Honkoop PJC, van der Meer J (1998) Experimentally induced effects of water temperature and immersion time on reproductive output of bivalves in the Wadden Sea. J Exp Mar Biol Ecol 220:227-246

Hovgaard P, Mortensen S, Strand Ø (2001) Skjell - biologi og dyrking. Kystnæringen Forlag \& Bokklubb, Bergen

Johannessen OM, Bengtson L, Miles MW, Kuzmina SI and 8 others (2004) Arctic climate change: observed and modeled temperature and sea-ice variability. Tellus Ser A 56: 328-341

Levitus S, Antonov JI, Boyer TP, Stephens C (2000) Warming of the world ocean. Science 287:2225-2229

Lønne I, Nemec W (2004) High-arctic fan delta recording deglaciation and environmental disequilibrium. Sedimentology 51:553-589

Mangerud J (1977) Late Weichselian marine sediments containing shells, foraminifera, and pollen, at Ågotnes, western Norway. Nor Geol Tidsskr 57:23-54

Mangerud J, Svendsen JI (1992) The last interglacial-glacial period on Spitsbergen, Svalbard. Q Sci Rev 11:633-664

Martinsen E, Engedahl H (1987) Implementation and testing of a lateral boundary scheme as an open boundary condition in a barotropic model. Coast Eng 11:603-627

Orvik KA, Niiler P (2002) Major pathways of Atlantic water in the northern North Atlantic and Nordic Seas toward Arctic. Geophys Res Lett 29:1896-1899

Orvik A, Skagseth Ø (2003) The impact of the wind stress curl in the North Atlantic on the Atlantic inflow to the Norwegian Sea toward the Arctic. Geophys Res Lett 30:1884-1887

Palerud R, Gulliksen B, Brattegard T, Sneli JA, Vader W (2004) The marine macro-organisms in Svalbard waters. In: Presterud P, Strøm H, Goldman HV (eds) A catalogue of the terrestrial and marine animals of Svalbard. Skrifter 201, Norwegian Polar Institute, Tromsø

Peacock JD (1989) Marine molluscs and later Quaternary environmental studies with particular reference to the late glacial period in northwest Europe: A review. Q Sci Rev 8: 179-192

Rahmstorf S (2002) Ocean circulation and climate during the past 120,000 years. Nature 419:207-214

Reistad M, Iden K (1998) Updating, correction and evaluation of a hindcast data base of air pressure, wind and waves for the North Sea, the Norwegian Sea and the Barents Sea. DNMI Res Rep 9, Norwegian Meteorological Institute, Oslo 
Rózycki O (1987) Marine bivalve molluscs of Svalbard. Polar Res 5:257-260

Salvigsen O (2002) Radiocarbon dated Mytilus edulis and Modiolus modiolus from northern Svalbard: climatic implications. Nor Geograf Tidskrift 56:56-61

Salvigsen O, Forman SL, Miller GH (1992) Thermophilous mollusks on Svalbard during the Holocene and their paleoclimatic implications. Polar Res 11:1-10

Sarnthein M, Van Kreveld S, Erlenkreuser H, Grootes PM, Kucera M, Pflaumann U, Scholz M (2003) Centennial-tomillenial-scale periodicities of Holocene climate and sediment injections off the western Barents shelf, $75^{\circ} \mathrm{N}$. Boreas 32:447-461

Schauer U, Fahrbach E, Østerhus S, Rohardt G (2004) Arctic warming through the Fram Strait: oceanic heat transport

Editorial responsibility: Howard I. Browman (Associate Editorin-Chief), Storebø, Norway from 3 years of measurements. J Geophys Res 109:1-14 Skogseth R, Haugan PM, Jakobsson M (2005) Water mass transformations in Storfjorden. Cont Shelf Res 25:667-695

Slagstad D, McClimans T (in press) Modelling the ecosystem dynamics of the Barents Sea including the marginal ice zone. I. Physical and chemical ceanography. J Mar Syst

Støle-Hansen K, Slagstad D (1991) Simulation of currents, icemelting and vertical mixing in the Barents Sea using a 3-D baroclinic model. Polar Res 10:33-44

Swift JH, Aagaard K (1981) Seasonal transitions and water mass formation in the Iceland and Greenland Sea. DeepSea Res 28:1107-1129

Thorarinsdóttir GG, Gunnarson K (2003) Reproductive cycles of Mytilus edulis L. on the west and east coast of Iceland. Polar Res 22:217-223

Submitted: February 10, 2005; Accepted: May 24, 2005 Proofs received from author(s): October 7, 2005 